\section{Sebaceous glands within odontogenic cysts}

\section{Odontojen kistlerde yağ bezi lobulüsü}

Assist. Prof. Nihan Aksakallı

Istanbul University, Institute of Oncology, Department of Tumor Pathology, Istanbul Orcid ID: 0000-0002-2380-1148

Received: 10 August 2018

Accepted: 27 December 2018

doi: 10.5505/yeditepe.2019.70288
Corresponding author:

Assist. Prof. Nihan Aksakalli

Istanbul University, Institute of Oncology,

Department of Tumor Pathology,

Block A, Floor 2, 34093, Çapa, Istanbul

Phone: +90 21241424 34/34202

Fax: +90 2125348078

E-mail: aksakallinihan@gmail.com

\section{SUMMARY}

Aim: Sebaceous glands are rarely observed in odontogenic cysts whereas these structures are the histopathologic features of dermoid cysts. Dermoid cyst growth is slow and its biologic behaviour is silent; after the cyst is removed, recurrence is not observed. However, there are some developmental odontogenic cysts that have a local aggressive course and high levels of recurrence and sebaceous glands may present in these types of cyst. The aim of the study is to evaluate the histopathologic and clinical features of odontogenic cyst with sebaceous gland. Materials and Method: 14 odontogenic cysts with sebaceous glands were reported in the present study. Histopathological features, locations and numbers of sebaceous glands were evaluated. Histochemical (PAS) and immunohistochemical (S100 protein, Pan Cytokeratin, Cytokeratin 19 and EMA ) examinations were also performed.

Results: In the present study, 14 patients, 9 (64\%) male and $5(36 \%)$ female with a mean age of 42 years were included. The cysts were located in the mandible of 10; while four of them were in the maxilla. All lesions were developmental odontogenic cysts. Microscopic evaluation revealed that sebaceous glands were only in the fibrotic cyst wall in 11 cases, in the intraepithelial location in 1 case and 2 cases showed three different sites as intraepithelial, subepithelial and wall.

Conclusions: When the sebaceous glands are observed histopathologically, there is a tendency to diagnoisis as a dermoid cyst. Therefore, the differential diagnosis between odontogenic cyst with sebaceous glands and intraosseous dermoid cysts has great importance for management or different follow-up options.

Keywords: Odontogenic cyst, intraosseous dermoid cyst, sebaceous glands, jaw cyst.

\section{ÖZET}

Amaç: Dermoid kistlerde bulunan yağ bezi lobulüsü odontojen kistlerde enderdir. Dermoid kistler yavaş büyür ve biyolojik davranışları sesizdir, kist çıkartıldıktan sonra yerel yineleme görülmez. Oysaki bazı gelişimsel odontojen kistler lokal agresif bir klinik gidiş gösterir, yerel yineleme oranları yüksektir; bu tip kistlerde yağ bezi lobülüsü bulunabilir. Bu çalışmanın amacı yağ bezi lobülüsü içeren odontojen kistlerin klinik ve histopatolojik olarak incelenmesidir.

Gereç ve Yöntem: Çalışmada yağ bezi lobulüsü içeren 14 odontojen kist olgusunun histopatolojik özellikleri, yağ bezi lobulüslerinin sayısı ve yerleşim özellikleri dikkate alınarak incelendi. Histokimyasal (PAS) ve immunhistokimyasal (S100 proteini, Pan Sitokeratin, Sitokeratin 19 and EMA ) incelemeleri de yapıldı.

Bulgular: Çalışmada 14 olgu incelendi, bunların 9'u erkek (\%64), 5'i (\%36) kadındı. 14 odontojen kist olgusunun, 
10'u mandibulada, 4'ü maksillada bulunuyordu. Lezyonların hepsi gelişimsel odontojen kistti. Mikroskopik incelemede 11 olguda yağ bezi lobulusü yalnızca fibrotik kist duvarında, 1'inde yağ bezi lobulüsü epitel içinde yer almıştı, 2'sinde ise hem epitel içinde, hem epitelin hemen altında, hem de fibrotik duvarda izlendi.

Sonuç: Bir kistte histopatolojik olarak yağ bezi lobulüsü görüldüğünde dermoid kist tanısı koyulması eğilimi vardır. Bu nedenle ayırıcı tanıya yağ bezi lobulüsü içeren odontojen kistlerin alınması hasta yönetimi ve farklı izlem seçenekleri açısından oldukça önemlidir.

Anahtar kelimeler: Odontojen kist, intraosseöz dermoid kist, yağ bezi, çene kistleri

\section{INTRODUCTION}

Cysts are benign pathologic cavities of bone or soft tissue and are generally surrounded by a wall of connective tissue. A true cyst has an epithelium lining in the cyst wall, while epithelium does not exist in a pseudocyst. True cysts are largely present in jaw bones. ${ }^{1,2}$

If true cysts of the jaws originate from the odontogenic epithelium, they are known as odontogenic cysts; if they originate from other epithelial structures, they are known as non-odontogenic cysts. ${ }^{3}$

Dermoid cysts (DmCs) are developmental cysts and teratomatous lesion that originate from ectoderm and mesoderm. DmCs develop extraorally, or rarely, intraorally, in soft tissue. Intraosseous development is very rare. Histopathologically, they lined with keratinized stratified squamous epithelium and one or more dermal appendages such as hair follicles, sweat glands or sebaceous glands in the wall.4-7

Epithelium of odontogenic cysts originate from epithelial cell rests of Malassez; dental lamina (epithelial cell rests of Serres); enamel organ and reduced enamel epithelial cells; dental papilla (ectomesenchyme); and basal layer cells of the oral epithelium. Histopathologically, the lining epithelia of these cysts consist of stratified squamous epithelium, single layer cuboidal, ciliated, ciliated low columnar cells, and pseudostratified squamous epithelium. Odontogenic cysts may also have sebaceous glands..$^{8-16}$ Sebaceous glands (SGs) are holocrine glands located adjacent to hair follicles. Secretions of SGs contain a complex mixture of lipids. The only areas in the body without SGs are the palms of the hands and soles of the feet. There are numerous SGs in facial skin. They are also found in the mouth, prepuce, labia minora, and sometimes in

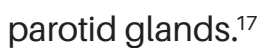

Ectopic sebaceous glands are called Fordyce's spots (or Fox-Fordyce granules), and they are frequent in the mouth, the vermillion, in the corners of the mouth or in the buccal mucosa in adults. Their numbers increase with age, and they are prevalent in $70 \%$ to $80 \%$ of the elderly.
They have sometimes been identified in the alveolar mucosa and dorsum of the tongue. In this group, ectopic sebaceous glands are considered normal.18,19

The presence of sebaceous glands in the oral mucosa may be due to an error in embryologic development through which some potential of skin ectoderm is retained in the ectoderm, which invaginates to form the linings of the oral cavity. ${ }^{19}$

The origins of intraosseous dermoid cyst (iDmC) are not clear. It might be the proliferation of the sequestration of embryonic ectoderm that may have been embedded in the developing jaw during embryogenesis, or development from odontogenic epithelial remains as a result of dermal metaplasia. ${ }^{20-22}$

The aim of the study is to state the histopathologic and clinical features of odontogenic cyst with SGs.

\section{MATERIALS AND METHODS}

Formalin-fixed, paraffin embedded blocks of 14 cases of odontogenic cysts with sebaceous glands were collected from the archives of the Department of Tumor Pathology, Institute of Oncology, Istanbul University between 20072015 years. The slides were reviewed and the cases were reevaluated with clinical and radiologic documentation by two blinded oral pathologists.

The study was approved by the Research Ethics Committee of Istanbul University (Number: 211).

\section{Statistical Analysis}

Statistical analyses were computed with proportion (\%) and $95 \%$ confidence interval (Cl) for each group.

\section{RESULTS}

We had 14 cases of odontogenic cysts with sebaceous glands. Table 1 shows clinicopathologic characteristics of these cases. Nine of the patients were male $(9 / 14 ; 64 \%)$ and five were female $(5 / 14 ; 36 \%)$. The mean age was 42 years (range, 14-73 years). The cysts were mostly prevalent among patients in sixth decade (6 patients), and followed by adults in third decade (4 patients).

The cysts were located in the mandible of 10 patients (10/14; 71\%); while four of them were in the maxilla (4/14; $29 \%$ ). Eight of the lesions were associated with impacted teeth $(8 / 14 ; 57 \%)$, five of which were canines $(5 / 8 ; 63 \%)$ and three were third molars $(3 / 8 ; 35 \%)$.

In 12 cases, lesions were unilocular (12/14; 89\%), 11 of which were radiolucent $(11 / 12 ; 92 \%)$, and one was radiolucent-radiopaque (1/12; 8\%). 10 lesions were well-defined with sclerotic borders (10/12; 83\%) and two had scalloped sclerotic borders $(2 / 12 ; 17 \%)$. In two cases, lesions had multilocular radiolucent appearance with well-defined margins $(2 / 14 ; 14 \%)$.

All lesions were developmental odontogenic cysts

(Figure 1). 

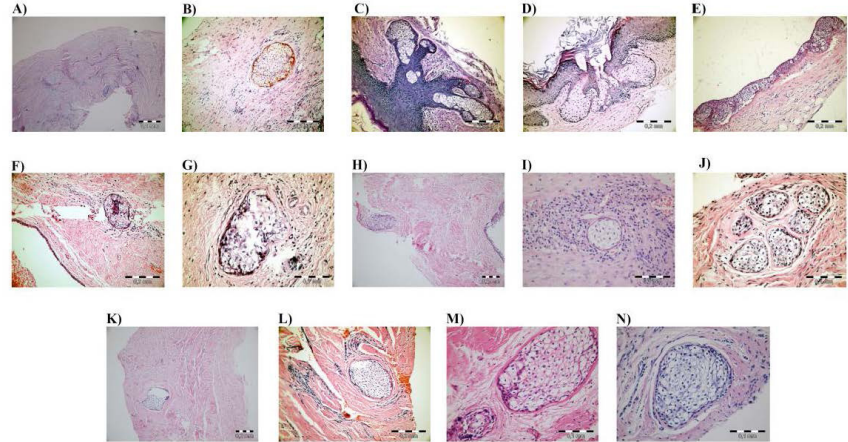

Figure 1. Selected photomicrographs of odontogenic cysts with sebaceous glands, A: Hematoxylin and Eosin (H\&E) staining (original magnification $\times 100$ scale bar $=0.1 \mathrm{~mm}$ ); $\mathrm{H}$, K: H\&E staining (original magnification $\times 100$; scale bar $0.2 \mathrm{~mm}$ ); $\mathrm{B}, \mathrm{D}, \mathrm{E}, \mathrm{F}, \mathrm{L}: \mathrm{H}$ \&E staining (original magnification $\times 200$; scale bar $=0.2$ $\mathrm{mm}$ ); C) Periodic acid-Schiff (PAS) staining (original magnification $\times 200$; scale bar= $0,2 \mathrm{~mm}$ ); G, I, J, M, N: H\&E staining (original magnification $\times 400$; scale bar= $0.1 \mathrm{~mm})$

Seven were dentigerous cysts (DC) $(7 / 14 ; 50 \%)$; one of these was associated with a compound odontoma. Three were odontogenic keratocysts (OKC) $(3 / 14 ; 21 \%)$. Two were orthokeratinized odontogenic cysts (OOC) (2/14; 14\%). Two were glandular odontogenic cysts (GOC) (2/14; $14 \%)$.

Table 2 summarizes the histopathological features, and locations and numbers of SGs. Microscopic evaluation revealed that in 11 cases, SGs were only in the fibrotic cyst wall, distant to the epithelial lining (Figure $1 \mathrm{~A}, \mathrm{~B}, \mathrm{~F}-\mathrm{N}$ ); SGs were observed to be focal in all of these cases. In eight of these cases, SGs were only in one focus and had only one lobule (Figure $1 \mathrm{~B}, \mathrm{~F}, \mathrm{G}, \mathrm{H}-\mathrm{L}, \mathrm{N}$ ), in one case, the SGs were in one focus but had two lobules (Figure $1 \mathrm{M}$ ). In two cases, SGs were observed in two foci; of these, one had two lobules in each focus (Figure $1 \mathrm{~A}$ ) and the other had six lobules in one focus (Figure $1 \mathrm{~J}$ ) and one lobule in the other focus. In one case, SGs were only observed intraepithelially, with one focus and three lobules (Figure $1 \mathrm{D}$ ). In two cases, SGs were observed intraepithelially, and subepithelially located, subjacent to the epithelium and in the fibrotic cyst wall, distant to the epithelial lining. Three foci were seen in one of these cases, one intraepithelial focus with seven lobules (Figure $1 \mathrm{C}$ ), one subepithelial focus with one lobule subjacent to the epithelium

(Figure 2A)
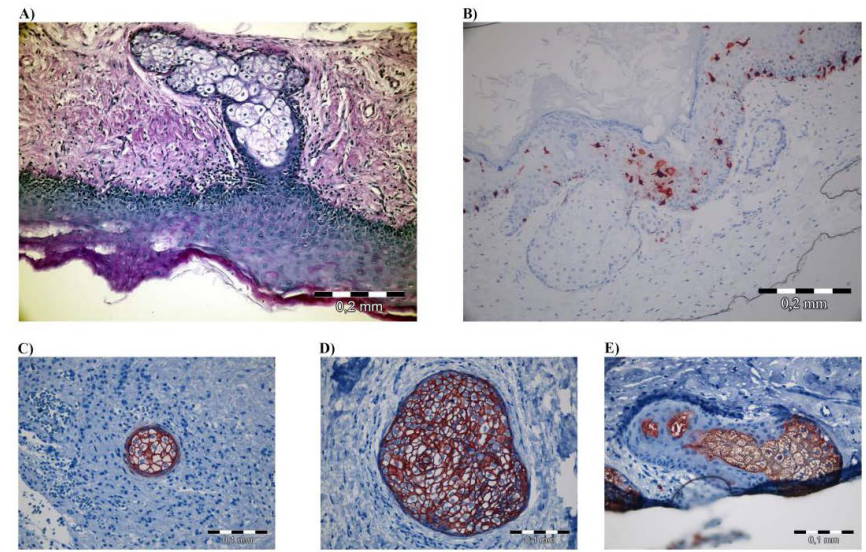

Figure 2. Selected photomicrographs of histochemical and immunohistochemica features of odontogenic cyst with sebaceous glands, Negative staining for A: Pe riodic acid-Schiff (PAS) staining (original magnification $\times 200$; scale bar $=0.2 \mathrm{~mm}$ ) B: S-100 protein antibody (original magnification $\times 200$; scale bar $=0.2 \mathrm{~mm}$ ); Strong immunoreactivity for C: Pan-cytokeratin antibody, D: Cytokeratin 19, E: Epithelia Membrane Antigen (EMA) antibody (original magnification $\times 400$; scale bar $=0.1 \mathrm{~mm}$ ) and one focus had two lobules without epithelial lining in the fibrotic cyst wall. In the last case, the SGs were observed as diffusely intraepithelial (Figure $1 \mathrm{E}$ ), two subepithelial foci had two lobules subjacent to the epithelium, and two foci had two lobules without epithelial lining in the fibrotic cyst wall. This was the only case with diffusely intraepithelial SGs.

Histochemical and immunohistochemical examinations were also performed to determine the origin of these rare stuructures, sebaceous glands. The cytoplasms of these sebaceous glands cells were negative for periodic acid-Schiff (PAS) staining (Figure 1C, 2A). The SGs revealed no cytoplasmic immunoreactivity with S-100 protein (Figure 2B), but had strong cytoplasmic immunoreactivity with Pan Cytokeratin (AE1/AE3) antibody and Cytokeratin 19 antibody, and strong membranous and cytoplasmic immunoreactivity with Epithelial Membrane Antigen (EMA) antibody (Figure $2 \mathrm{C}$-E).

Enucleation was performed for the treatment of all lesions while decompression was also carried out six months prior to enucleation in one of the cases. The patients were followed up for 8 to 96 months. No recurrence was observed (Table 1). 
Table 1. Clinicopathologic characteristics of patients have odontogenic cysts with sebaceous glands

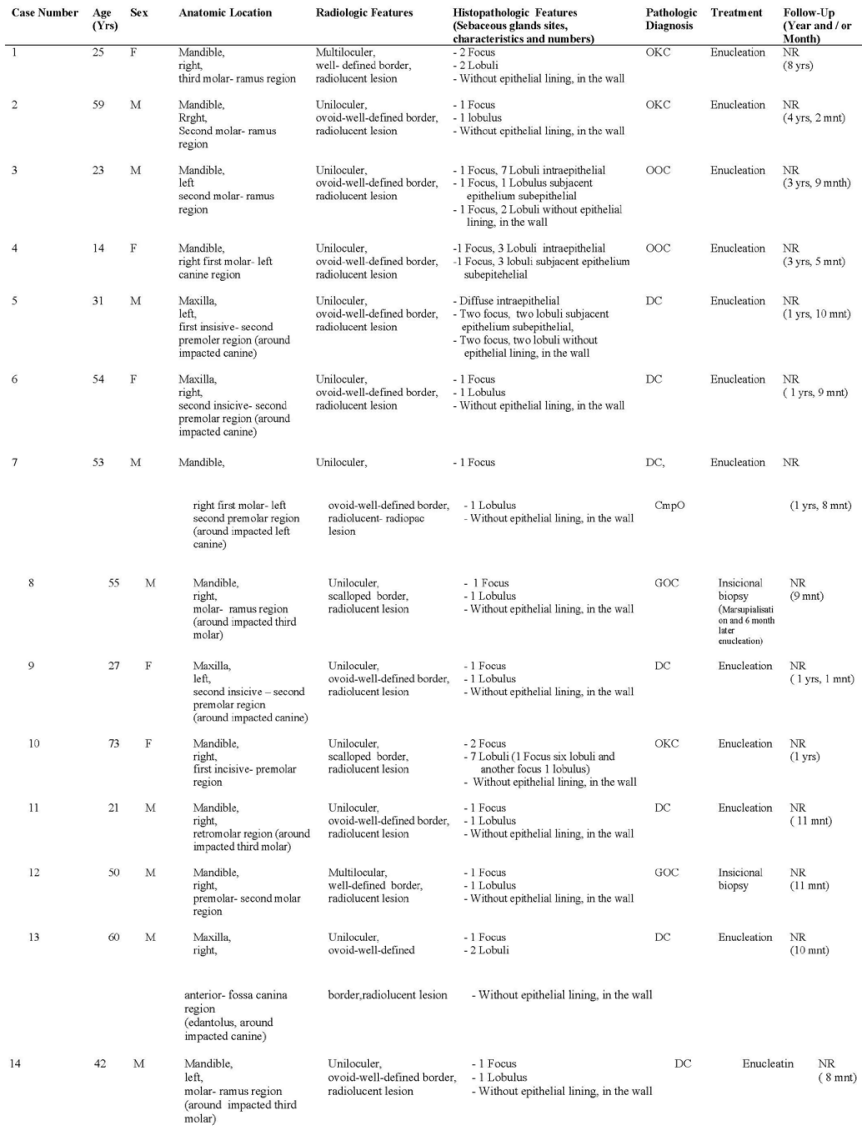

OKC: Odontogenic Keratocyst, OOC: Orthokeratinized Odontogenic Cyst, DC: Dentigerous Cyst, GOC: Glandular Odontogenic Cyst,

CmpO: Compound Odontoma, NR: No Residive, Yr: Year, Mnt: Month

Table 2. Microscopic Features and Locations of Sebaceous Glands in Odontogenic Cysts

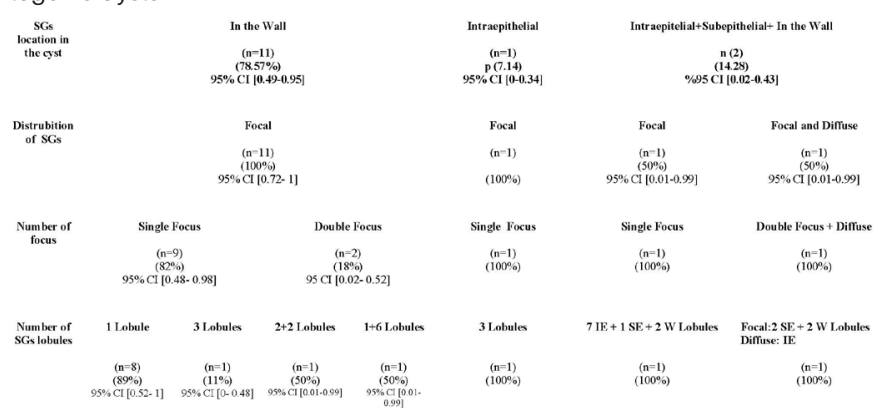

n: Case number ,Cl: Confidence Interval, W: In the wall, IE: Intraepithelial, SE: Su bepithelial, SGs: Sebaceous Glands

\section{DISCUSSION}

True cysts are seen most commonly in jaws compared with other parts of the body due to the large number of remains of odontogenic epithelium in oral tissues. Cysts of the head and neck region may originate from the embryogenic development of enamel organ tissue (odontogenic cysts), epithelial remnants of maxillofacial embryogenesis (nonodontogenic cysts, fissural cysts, thyroglossal ductal cysts, dermoid and epidermoid cysts), or epithelial tissue traumatically embedded underneath the oral mucosa (inclusion cysts, entrapment cysts). ${ }^{23}$

Developmental cysts are rare in the head and neck region, whereas dermoid cysts are relatively frequent. Dermoid cysts that are found in the oral cavity are mostly observed in the floor of the mouth between the hyoid bone and the jaw, because they originate from entrapped embryogenic epitheilial remnants within the soft tissue and the bone between the mandibular arches and the tongue. Some authors argue that the endodermal epithelium of the floor of the mouth cannot be distinguished from ectodermal oral epithelium in this region. The remnants that give rise to developmental cyst may be of either origin. ${ }^{5,24}$ The lesion may be present at birth and among the elderly; the majority of lesions develop between the ages of 25 and 35 years. They are slightly more common among males. ${ }^{4-7,23}$

Histopathologically, dermoid cysts are lined with keratinizing stratified squamous epithelium. In the fibrotic cyst wall, one or more dermal appendages such as hair follicles and sweat or sebaceous glands are seen. Hair follicules are seldom. The lumen of the cyst is generally filled with desquamated keratin, which clinically gives them a soft consistency. ${ }^{24}$

Various hypotheses have been suggested for the etiopathogenesis of iDmC; it might be the sequestration of the part of the ectoderm that develops the oral cavity, which may have been embedded deep in the surface and entrapped in the developing mandible during embryogenesis, and might have been induced for proliferation by dental inflammation. Another hypothesis is that cysts develop from remains of odontogenic epithelium that change into dermal metaplasia. ${ }^{7,20-22,24}$

Allon et al. ${ }^{7}$ and Bodner et al. ${ }^{6}$ stated that the presence of SGs was an indispensable histologic element for the diagnosis of iDmC. SGs are essential for the diagnosis of DmC but any cyst with SGs may not be an iDmC. A small number of iDmCs have previously been reported. Some of these cysts, which were presented as iDmC, may actually have been odontogenic cysts with SGs. Therefore all clinical, radiological apperances and histopathological, especially the lining epitehelium features should be evaluated carefully to make a correct diagnosis.

Sebaceous glands may be present in odontogenic cysts. Odontogenic cysts are classified into two groups, inflammatory and developmental cysts, according to their etiopathogenesis. In inflammatory cysts, the inflammation present in the bone or arriving from the surrounding tissue, causes proliferation of cyst epithelial sources, but the etiology of proliferation is not known in developmental cysts. ${ }^{1,224-26}$ The theories related to the presence of SGs in odontogenic cysts state that SGs may be formed by metaplasia of the lining cyst epithelium or trapped epithelial rests in jaws. It is well understood that odontogenic epithelium has pluripotential capacity. It may differentiate into columnar cells, mucous cells, sebaceous cells, and other cell types. Some authors suggest that due to the induction between oral epithelium and the oral ectomesenchyme, numerous tissues or structures some of which are 
epithelial in origin, may occur. The induction of the oral ectomesenchyme to the multipotential oral epithelium, results in the differentiation of SGs. ${ }^{8-13,15,25}$ Some authors argue that the OKC is an intraosseous counterpart of epidermoid cysts located in the jaw. ${ }^{27,28}$

Some developmental odontogenic cysts, including botryoid odontogenic cysts, OKC and GOC have aggressive growth potential and high recurrence rates. The recurrence rates of these cyts have been reported approximately $30 \%$ in various studies (range 5\%-62\%), ${ }^{1,224,25}$ In our study, five cases were diagnosed as OKC $(n=3)$ and GOC $(n=2)$, which are known to have local aggressive biological behavior and high recurrence potential, and need non-conservative surgery and long-term follow-up. No recurrence was observed in our cases during follow-up period; however follow-up duration of four to 80 months might be short for recurrence.

Historically, the first study on odontogenic cyst with SGs was published by Hofraht in 1930.14,29 In 1957, Gorlin $^{8}$ described two DCs that had SGs, and then in 1966, Spouge9 reported SGs in DCs. Brannon10 was the first to describe odontogenic keratocysts (OKC) that had SGs in 1976. Craig et al. ${ }^{30}$ and Christensen and Proper11 presented other OKCs with SGs in 1980 and 1982, respectively. In 1993, Vahahula et al.12 reported that among 12 jaw cysts, one cyst had prominent orthokeratinized epithelial lining and sebaceous differentiation and diagnosed as an odontogenic cyst with SGs. In 2007, Chi et al. ${ }^{13}$ published a series of odontogenic cysts with sebaceous elements in 5 patients, all of which were OOC. Chi et al. ${ }^{13}$ conducted a review of studies of which 10 odontogenic cysts with sebaceous elements had been reported up until that time. In 2008, Shamim et al. ${ }^{14}$ reported that they observed SGs in a OKC. In 2011, Hosmani et al..$^{15}$ reported a DC with SGs. Kumar et al. ${ }^{16}$ reported an odontogenic cyst, a fibrotic cyst wall lined by parakeratinized squamous epithelium that showed hyperplasia with chronic inflammation and SGs inclusion and described it as a radicular cyst with sebaceous differentiation. We know that metaplastic keratinization may be present in radicular cyst epithelium, but we must also keep in mind that this cyst might have been an inflamed OKC.

In addition, Kumar et al..$^{16}$ suggested that malignant transformation might be expected in sebaceous glands metaplasia of odontogenic epithelium of a cyst and they should be categorized as a separate entity, but there were no supporting data.

Cawson et al. ${ }^{26}$ said that "SGs were common in the oral mucosa, but were not normally present within the jaw. Therefore, it was uncertain whether a jaw cyst containing sebaceous glands should be categorized as a variant of an odontogenic keratocyst or as a dermoid cyst" However, Cawson et al. ${ }^{26}$ were wrong. Other odontogenic cysts with SGs were also reported. In 1966, Spouge ${ }^{9}$ reported SGs on the wall of a dentigerous cyst and interpreted that as metaplastic change. Neville et al. ${ }^{25}$ noted that small nests of sebaceous cells might rarely be seen within the fibrous cyst walls of dentigerous cysts. Chi et al. ${ }^{13}$ reported 5 OOC with SGs cases and suggested that the other cases might also have been examples of OOC with SGs. However, in our study, there were developmental odontogenic cysts other than DCs and OOCs. Seven of the cases were DCs and three were OKCs, two were OCCs and two were GOCs with SGs. It is clear that fibrotic cyst walls were lined by nonkeratinized epithelium in nine cases.

In our study, of the total 14 cases, eight were present with an impacted tooth and five were in the canines, three with third molar teeth, seven were DCs, and one was defined as GOC. It is not possible to say that these were not odontogenic cysts simply by examining the SGs. Takeda et al. ${ }^{21}$ noted that "metaplastic sebaceous glands were not widely distributed in the cyst wall of OKCs and OOCs, and the connective tissue layer was not involved." We observed SGs in 11 cases in only the fibrotic wall and two cases showed both with intraepithelial and wall locations.

To our knowledge 17 odontogenic cysts with SGs have been reported until now. Herein, we report 14 cases of odontogenic cysts with SGs.

The presence of SGs in odontogenic cysts has been defined in various ways as "sebaceous metaplasia", "sebaceous differentiation", and "sebaceous elements". 9,13,14 Different terms for same lesions lead to confusion, thus common language will be more helpful to define these SGs.

These cysts have been published under various names, Cawson et al. ${ }^{26}$ defined them as odontogenic keratocyst, and Neville et al. ${ }^{25}$ opted for dentrigerous cysts. It is not correct to define these cysts as "intraosseous mandibular cysts" or "mandibular cysts with sebaceous differentiation" because four of the cases in our series, and one each for Spouge, ${ }^{9}$ Vahahula, ${ }^{12}$ Chi et al., ${ }^{13}$ and Kumar et al. ${ }^{16}$ found them located in the maxilla.

In conclusion, SGs may be present in odontogenic cysts and histopathological diagnosis has great importance when they are seen. The differential diagnosis of these cysts must be performed more carefully to distinguish from iDmC which has slow growing, benign biologic behaviour and lack of local recurrence. Because there are some developmental odontogenic cysts that have local aggressive progress with the possibility of local recurrence. The management of these odontogenic cysts is totally different than for iDmC. There is no alternative management or different follow-up options for maxillofacial surgeons because odontogenic cysts with SGs do not have a different biologic behavior to odontogenic cysts alone. Therefore, the presence of SGs in odontogenic cysts must 
be followed up separately, and documented in detail. The need for a separate classification of these cysts must be further discussed.

\section{AKNOWLEDGEMENTS}

We want to thank Dr. Vakur Olgac, Dr. Canan Alatli and Dr. Rian Disci for valuable consideration of the cases and also thanks to techinal team for their efforts. The special thanks to the photografher, Kemal Aslan, for his support of the figures.

\section{REFERENCES}

1. Regezi JA, Sciubba JJ, Jordan RCK. Chapter 10 Cyst of the Jaws and Neck. In: Oral Pathology Clinical Pathologic Correlations. 7th ed. St. Louis, Missouri, Elseviere; 2017. p.245-266.

2. Tekkesin MS, Olgac V, Aksakalli N, Alatli C. Odontogenic and nonodontogenic cysts in Istanbul: analysis of 5088 cases. Head Neck 2012; 34: 852-855.

3. Slootweg PJ. Lesions of the jaws. Histopathology 2009; 54: 401-418.

4. Wenig BM. Section 4. The Neck. Chapter 12 Non- Neoplastic Lesions of the Neck. In: Atlas of Head and Neck Pathology. 3rd. ed. Philadelphia, Elsevier: 2016. p.549550.

5. Torske KR, Benson GS, Warnock G. Dermoid cyst of the maxillary sinus. Ann Diagn Pathol 2001; 5: 172-176.

6. Bodner L, Woldenberg Y, Sion-Vardy N. Dermoid cyst of the maxilla. Int J Oral Maxillofac Surg 2005;34:453-455.

7. Allon DM, Calderon S, Kaplan I. Intraosseous Compound-type Dermoid Cyst of the Jaw. Case Report. IJHNS 2010; 1: 103-106.

8. Gorlin RJ. Potentialities of oral epithelium manifest by mandibular dentigerous cyst. Oral Surg Oral Med Oral Pathol 1957; 10: 271-284.

9. Spouge JD. Sebaceous metaplasia in the oral cavity occurring in association with dentigerous cyst epithelium. Report of a case. Oral Surg Oral Med 1966; 21: 492498.

10. Brannon RB. The odontogenic keratocyst. A clinicopathologic study of 312 cases. Part II. Histologic features. Oral Surg Oral Med Oral Pathol 1977; 43: 233-255.

11. Christensen RE Jr, Propper RH. Intraosseous mandibular cyst with sebaceous differentiation. Oral Surg Oral Med Oral Pathol 1982; 53: 591-595.

12. Vuhahula $E$, Nikai $H$, ljuhin $N$, Ogawa I, Takata T, et al. Jaw cysts with orthokeratinization: analysis of 12 cases. J Oral Pathol Med 1993; 22: 35-40.

13. Chi AC, Neville BW, McDonald TA, Trayham RT, Byram $J$, et al. Jaw cysts with sebaceous differentiation: report of 5 cases and a review of the literature. $J$ Oral Maxillofac Surg 2007; 65: 2568-2574.

14. Shamim T, Varghese VI, Shameena PM, Sudha S. Sebaceus differantiation in odontogenic keratocyst. Indian J Pathol Microbiol 2008; 51: 83-84.

15. Hosmani JV, Hugar D, Nayak RS. Dentigerous cyst with sebaceous differantiation. http://guident.net/articles/oral-pathology/152-dentigerous-cyst-with-sebaceous-differentiation.html. 2011. access 10.08.2018.

16. Kumar M, Modi TG, Bajpai M, Nanavati R. Rare presentatin of radicular cyst with sebaceous differantiation. S J Oral Sci 2014;1:120-122.
17. Li M, Urcmacher CD. Cutaneous Tissue. In: Mills SE, editor. Histology for Pathologists. 3rd ed. Philadelphia, Lippincott Williams \& Wilkins; 2007. p.3-56.

18. Balogh K. Mouth, Nose and Paranasal Sinuses. In: Sternberg SS, editor. Histology for Pathologists. 2nd ed. Philedelphia, Lippincott-Raven; 1997. p.367- 390.

19. Squier CA, Finkelstein MW. Oral Mucosa. In: Nanci A, editor. Ten Cate's Oral Histology. Development, Structure, and Function. 6th ed. St Louis, Missouri, Mosby; 2003. p.329- 375.

20. Komiyama K, Miki Y, Oda Y, Tachibana T, Okaue M, et al. Uncommon dermoid cyst presented in the mandible possibly originating from embryonic epithelial remnants. J Oral Pathol Med 2002; 31: 184-187.

21. Takeda $Y$, Oikawa $Y$, Satoh $M$, Nakamura S. Latent form of multiple dermoid cysts in the jaw bone. Pathol Int 2003; 53: 786-789.

22. Bodner L, Woldenberg Y, Sion-Vardy N. Dermoid cyst of the maxilla. Int J Oral Maxillofac Surg 2005; 34: 453455.

23. Bouqout JE, Müller $S$, Nikai H. 4. Lesions of the Oral Cavity. In: Gnepp DR, editor. Diagnostic Surgical Pathology of the Head and Neck. 2nd ed. Philadelphia, Elsevier; 2009. p.191-308.

24. Shear M, Speight PM. Cysts of the Oral and Maxillofacial Regions. 4th ed. Oxford, Blackwell Munksgaard; 2009: p.1-192.

25. Neville BW, Damm DD, Allen CMA, Chi AC. 15 Odontogenic Cyst and Tumors. In: Oral and Maxillofacial Pathology. 4th ed. St Louis, Missouri, Elsevier; 2016. p.632-689. 26. Cawson RA, Binnie WH, Speight PM, Barrett AW, Wright JM. Section 4. Odontogenic cysts. Part I. Developmental Cysts. In:. Lucas's Pathology of Tumors of the Oral Tissues. 5th ed. London, Churchill Livingstone; 1999. p.119-126.

27. Pimpalkar RD, Barpande SR, Bhavthankar JD, Mandale MS. Bilateral orthokeratinised odontogenic cyst: A rare case report and review. J Oral Maxillofac Pathol 2014; 18: 262-266.

28. Abé T, Maruyama S, Yamazaki M, Essa A, Babkair $\mathrm{H}$, et al. Intramuscular keratocyst as a soft tissue counterpart of keratocystic odontogenic tumor: differential diagnosis by immunohistochemistry. Hum Pathol 2014; 45: 110-118.

29. Hofrath $\mathrm{H}$. Uber das vorkommen Von Talgdrussen in der Wandung einer Zahncyste, Zugelich ein Beitrag zur Pathogenese der kiefer-Zahncysten. Dtsch Monatsschr Zahn heilkd 1930; 2: 65-76.

30.Craig GT, Holland CS, Hindle MO. Dermoid cyst of the mandible. Br J Oral Surg 1980; 18: 230-237. 